23. Ilariene I. Kilka Zrodel dotyczacych protektoratu Wielkiego Księstwa Litewskiego nad arcybiskupstwem Ryskim // Lietuvos Didžiosios Kunigaikštystės istorijos šaltiniai: Faktas. Kontekstas. Interpretacija. Vilnius: Leidykla, 2007. S. 213-240.

24. Seraphim E. Geschichte von Livland. Gotha: F.A. Perthes, 1906. Bd. 1. $293 \mathrm{~s}$.

25. Monumenta Livoniae Antiquae. Sammlung von Chroniken, Berichten, Urkunden und andern schriftlichen Denkmalen und Aufsätzen, welche zur Erläuterung der Geschichte Liv-, Ehst-und Kurland's dienen. Riga; Leipzig: Eduard Frantzen's VerlagsComptoir, 1847. Bd. 5. $860 \mathrm{~s}$.

26. Deggeller G. Karl V und Polen-Litauen. Ein Beitrag zur Frage der Ostpolitik des späten Kaisertums. Würzburg: Triltsch, $1939.49 \mathrm{~s}$.

27. Gudavičius E. Lietuvos europejimo kelias: istorinès studijos. Vilnius: Aidai, 2002. 383 p.

28. Arbusow L. Die Einführung der Reformation in Liv-, Est- und Kurland. Leipzig: Scientia Verlag Aalen, 1921. $851 \mathrm{~s}$.

\title{
GENESIS AND TRANSFORMATION OF POLISH-LITHUANIAN SOVEREIGNS PROTECTORSHIP RIGHT OVER THE LIVONIAN CONFEDERATION LANDS
}

(C) 2017

\section{Bessudnov Daniil Alexandrovich, postgraduate student of Slavic and Balkan Countries History Department Saint Petersburg State University (Saint Petersburg, Russian Federation)}

Abstract. As known, from the end of the XV century Livonia became the object of close attention of the sovereigns As known, since the end of the XV century Livonia became the object of close attention of the sovereigns of Denmark, Sweden, the Grand Duchy of Lithuania, the Crown of Poland and the Moscow State, who were attracted by its favorable strategic position, an important role in the international Baltic trade and rich land resources. However, the possibility of direct expansion by the Catholic states was limited by the status of Livonia as a «crusading state», under the auspices of the two most influential political assemblies of Catholic Europe - the Pope and the Holy Roman Empire of the German nation. An interesting way to bypass this obstacle was used by the rulers of the PolishLithuanian state, who applied a special form of political expansion that did not violate or at least created an appearance of preserving the papal and imperial prerogatives, and at the same time allowed them to postulate themselves as their legitimate implementers. That was promoted by the ancient political and legal concept according to which they acted as protectors and conservators of the states of the Livonian Confederation. It emerged in the XIV century, but, however, it was fully in demand by the rulers of the Polish-Lithuanian state only in the XVI century, when Livonia became the main object of the «battle for the Baltic» and a very interesting problem is the historical roots and the modification of this political concept from the time of its appearance to its finalization.

Keywords: Livonia; Livonian confederation; Livonian order; diocese of Riga; Crown of Poland; Poland; Poland kingdom; Grand duchy of Lithuania; GDL; Vytautas; Sigismund I; Sigismund II August; Fromhold von Vifhusen; Henning Scharpenberg; Bernhard von der Borch; Johannes VII von Blankenfelde; Wolter von Plettenberg.

УДК 94(470)"16"-057.34

Статья поступила в редакцию 06.10.2017

\section{ПРИКАЗНЫЕ СТАВЛЕННИКИ СИГИЗМУНДА ІІІ ПРИ НОВОМ ЦАРЕ М.Ф. РОМАНОВЕ} (C) 2017

Рыбалко Наталия Владимировна, кандидат исторических наук, доцент кафедры истории России Ивина Анастасия Викторовна, хранитель фондов музейного комплекса Волгоградский государственный университет (г. Волгоград, Российская Федераиия)

Аннотаиия. В статье рассматривается ключевой вопрос системы управления переходного периода - от времени Междуцарствия Российского царства - к формированию правительства нового государя Михаила Романова. Биографии приказных служащих (дьяков и подьячих) завершающего периода Смуты восстановлены по отдельным упоминаниям, преимущественно в актовом материале и документах официального делопроизводства. С применением метода просопографии проведена систематизация биографических сведений об отдельных лицах и анализ коллективного портрета служащих, что позволило выявить общую государственную политику в отношении управленцев высшего и среднего звена центрального аппарата управления.

В результате проведенного исследования удалось установить, что из 73 человек, зафиксированных на службе в боярском правительстве Москвы и при Сигизмунде III, 36 человек продолжили работу в новом правительстве Михаила Романова. Из 9 думных дьяков - 3 человека, из 37 дьяков - 22 человека, из 27 подьячих 
при Михаиле Романове упоминаются 11 человек. Учитывая, что данные о подьячих носят отрывочный характер, можно заключить, что опала коснулась преимущественно думных дьяков. Служащие среднего звена как управленцы-профессионалы, в большинстве своем, не были отстранены от работы по политическим мотивам, что соотносится с общей тенденцией Смутного времени начала XVII в. Дьяческий состав на $60 \%$ оставался прежним, обеспечивая профессионализм в сфере управления.

Ключевые слова: Смутное время; история России; Московское государство; XVII век; Междуцарствие; дьяки; думные дьяки; подьячие; приказы; Михаил Романов; Сигизмунд III; метод просопографии; реконструкция биографий; центральное управление; боярское правительство; приказные служащие; правительство царя Михаила Романова.

Бурные события Смутного времени начала XVII века стали серьезным испытанием для каждого человека Русского государства не только в экономическом, но и в политическом, и в нравственном отношении. Данные вопросы касались, прежде всего, государственной службы и лиц, на ней находившихся. Особенно сложно было сделать правильный выбор в эпоху Междуцарствия ввиду отсутствия определенности: кто же является настоящим правителем - «истинный царь Дмитрий», королевич Владислав? Нужно ли подчиняться указам боярского правительства или лидеров ополчений?

Неудачи с Лжедмитрием II дали возможность Сигизмунду III получить приверженцев среди русских бояр и дворян, что позволило создать фактически свое собственное правительство с марта 1610 г. по октябрь 1612 г. Некоторые приказные деятели также стали содействовать иностранному государю и за это получили должности, земли и другие пожалования от короля, будучи в составе приказов боярского правительства. Деятельность Сигизмунда III по назначению в приказы дьяков и подьячих в конце 1610 начале 1611 г. спровоцировала начало активной фазы протестного земского движения в защиту православной веры и Русского государства [1]. Однако лишь единицы из тех, кто поддержал польского короля и боярское правительство, перешли в ополчение. Большинство, получив земельные пожалования в течение 1610 г., продолжали работу в составе уже фактически парализованного боярского правительства в осаде в Кремле. Какова же была их дальнейшая судьба? Удалось ли людям, составившим, по сути, политическую оппозицию сначала Василию Шуйскому, затем правительствам земских ополчений, закрепиться при новом царе Михаиле Романове?

Сложностью в работе является отсутствие источников сводного характера, которые бы содержали биографическую информацию о перестановках в правительстве и центральных учреждениях. В данной ситуации результативным является метод просопографии, применяемый исследователями в данной области знаний. С реконструированными биографиями служащих приказного аппарата управления Московского государства, которые служили и в период Междуцарствия, с разной степенью подробности можно ознакомиться в трудах А.П. Барсукова [2], С.Б. Веселовского [3], Д.В. Лисейцева [4], Н.В. Рыбалко [5]. Но дальнейшая судьба приказных людей этого периода как самостоятельный вопрос исследователями не рассматривалась.

Н.В. Рыбалко были выявлены дьяки и подьячие боярского правительства Москвы и распределены по приказам [5; 6]. Из 24 ведомств, функционировавших в период боярского правления, неизвестными остались имена дьяков и подьячих Конюшенного, Мона- стырского, Панского, Ямского, Стрелецкого, Пушкарского приказов, Судной избы, - в лучшем случае есть информация о руководителях - выходцах из княжеско-боярской аристократии. Цель данного исследования - проследить, как сложилась судьба после 1613 г. думных дьяков (далее в статье - д/д.), дьяков (далее в статье - д.) и подьячих (далее в cmaтьe - п.) из 17 приказов, кто принес присягу королевичу Владиславу и польскому королю Сигизмунду III в составе боярского правительства.

\section{Приказ Большого дворца.}

Дьяк Богдан Иванович Губин - п. с 1603 г., д. «при Литве» в 1610/11 г., д. в Первом ополчении в апреле 1611 г. [5, с. 90, 211, 230]. В 1613 г. вместе с Б.П. Шереметьевым был отправлен под Смоленск [7, стб. 104]. В 1613-1614 гг. - д. Стрелецкого приказа, с 1615 г. по 1619 г. - д. Казанского дворца [8, с. 2, 6, 17, 30, 113]. В 1617 г. встречал персидских послов, в январе 1618 г. - кызылбашского посланника [7, стб. 304, 309], в 1615 г. собирал пятинные деньги в Устюжском уезде, в 1619-1620 гг. его оклад - 80 руб. [9, с. 154]. В 1619-1621 гг. - д. в Ямском приказе, 12 октября 1621 г. назначен «разбирать» служилых людей на Туле с князем Ф.И. Лыковым, в 1638 г. встречаются упоминания об его дворе в Москве [3, c. 139].

Дьяк Гуляй Петрович Золотарев - д. с 1603/04 г., в феврале 1611 г. - д. в грамотах от Владислава, в декабре 1612 г. - д. в новом правительстве [5, с. 29, 211] в 1613-1614 гг. служил в Костромской чети [10, с. 33]. В 1615 г. - д. в Галиче [3, с. 197], в 16161617 гг. - в Великом Новгороде [8, стб. 18], в 16181619 гг. - в Арзамасе [11, с. 576]. В 1621-1623 гг. упоминается в объездах по Москве, затем в 16251631 гг. - во Владимирской чети, включая Галицкую [3, c. 198].

Дьяк Михаил Тюхин - п. с 1605/06 г., был в Тушине, д., «верный человек царя Владислава» в 1611 г. [5, с. 139, 211]. С 1615 по 1616/17 г. известен в Московском судном приказе [7, стб. 286]. Д.В. Лисейцев называет его одним из первых служащих после перерыва в работе данного приказа [12, c. 113]. С 1618 по 1620 г. был в посольстве к шаху Аббасу в Иран [7, стб. 311], получил за это 100 рублей $[9$, с. 573]. Ходил «без товарищей» к шаху, за что был приговорен к ссылке в Сибирь [3, с. 529].

Казенный двор. Казенные дьяки Меньшик [Булгаков] - д. с 1603 г. [5, с. 30] и Матвей Коробейников - д. с 1598 г. [5, с. 29-31], записавшие сведения о расхищении казны В. Шуйского после его пострижения [13], были смещены со своих должностей по приказу Сигизмунда III в начале 1611 г., о дальнейшей их судьбе неизвестно.

Новый штат приказа: казначей и думный дворянин Афанасий Иванович Власьев - п. с 1584 г., д. с 
1595 г. [3, с. 98], д/д. при Б. Годунове и до 20 января 1611 г. [5, с. 453], д. Иван Иванов Юрьев и д. Кирилл Сазонов сын Коробейников в декабре 1610 г. упоминаются впервые [5, с. 212]. Дальнейшая судьба всех троих неизвестна.

Дьяк Савва Романчуков - п. при царе Федоре Ивановиче [14, с. 352], Лжедмитрии I, перешел в Первое, затем Второе ополчения [5, с. 486], а при М.Ф. Романове - д. Посольского приказа после П.А. Третьякова. В августе 1614 г. отправлен «справлять» назначение к касимовскому царю, встречал послов в сенях в 1615 г., в 1616 г. встречал касимовского царя [7, стб. 142, 169, 222]. В 1620 г. ему отведено поместье в Ярославском уезде в 84 чети [9, с. 484]. 21 октября 1625 г. - д. Посольского приказа, одновременно в 1620-1624 гг. - д. Новгородской чети [3, c. 451]. Умер в 1624 г. [15, с. 116].

Дьяк Клементий Третьяк Григорьевич Корсаков п., д. с 1603/04 г., служил при Лжедмитрии I, В. Шуйском, в боярском списке 1610/11 г. значится «при Литве» [5, с. 119, 212-213], при М. Романове в июле 1621 г. - д. Разбойного приказа, в 1619-1622 гг. - д. Галицкой чети, с конца 1622 г. по 1626 г. д. Поместного приказа [3, с. 264].

Предположительно в Казенном приказе служил дьяк Иван Федоров - д. с 1587 г. [16, с. 191], был в приказах Б. Годунова, В. Шуйского, в феврале 1611 г. он составил переписной список царской казны [5, c. $31,98,190,191,212]$. Имя и фамилия очень распространенные, поэтому сделаем оговорку, что при условии, что это один и тот же человек, то служил дьяком Оружейного приказа в 1613 г. и продолжил службу далее [3, с. 541].

Новгородский дворец (г. Москва). Подьячий Богдан Афанасьев сын Фокин, удалось обнаружить единственное упоминание о его службе в апреле 1611 г. [17, с. 74].

В Московском Разряде в период боярского правления служили 4 дьяка.

Думный дьяк Василий Осипович Янов (начал службу в Смоленске городовым дьяком с 1604 г. [18, c. 215], думный чин получил от Лжедмитрия I, д. в Разряде в конце 1610 г., д/д. - в феврале и июне 1611 г., был противником ополчений, после посольства 5 октября 1611 г. к Сигизмунду III [5, с. 128 , 152, 213-214] о нем ничего не известно.

Дьяк Андрей Вареев - д. с 1594 г. [14, с. 318], служил при В. Шуйском и был в Разряде боярского правительства осенью 1610 г. и в 1611 г., перешел в ополчение Д. Пожарского и за подмосковные службы в 1612-1613 гг. получил жалованье [5, с. 155, 213]. Подписался на выборе царя М. Романова в 1613 г. [3, с. 79]. С 8 сентября 1613 г. по 1615 г. - д. в Нижнем Новгороде [20, № 189, с. 859]. После Разбойного приказа с 24 апр. 1617 по 1619 г. - д. в Великом Новгороде [10, с. 540-543]. В 1617-1619 гг. отдал думному дьяку П. Третьякову из своего поместья в Рязани 60 четей, а тот взамен ему отдал 148 и $3 / 4$ четей из Вологодского уезда, итого его оклад 800 четей, к его луховскому и рязанскому поместьям в 687 четей [21, с. 127], в октябре 1619 г. - д. в Разбойном приказе, в 1621-1622 гг. - в Поместном приказе, в 1623-1627 гг. - в Пушкарском приказе, в 1628-1630 гг. - в Свияжске, его оклад 100 рублей и 800 четей [3, с. 79-80]. В 1626-1627 гг. имел вотчин- ную деревню Ковезина Московского уезда, в 16271629 гг. - поместье в Луховском уезде [9, с. 97].

Дьяк Истома Захарьевич Карташов - п. с $1587 / 88$ г., д. с 1596/97 г. [3, с. 230], служил боярскому правительству в июле - августе 1610 г. [10, с. 540; 22 , с. 237], в 1611 г. - д. в ополчении П. Ляпунова, затем во Владимире, на Вологде, где и был убит в сентябре 1612 г. [3, с. 231].

Дьяк Василий Михайлов Юрьев - п. с 1 мая 1605 г. [5, с. 67] вскоре после 20 января 1611 г. умер [23, № 314, c. 372; 24, c. 85].

В приказе известны 2 подьячих. Постник Матренин Дмитриев - до января 1612 г., вероятно, он же подьячий у Выми Яренской в 1615/16 г. [3, с. 153]. Подьячий Никифор Спиридонов - п. с 1601 г, упоминается до февраля 1611 г. [5, с. 50, 214], в 1613/141615/16 гг. - в Разрядном приказе [25, стб. 298, 345, $527,569]$, в январе 1620 г. - д. в Великом Новгороде, с 1627 г. по апрель 1633 г. - д. Костромской чети, в 1630 г. - д. Устюжской чети [3, с. 487], в 1633 г. - д. на Двине [9, с. 530].

В Новгородском Разряде были думный дьяк Евдоким Яковлевич Витовтов - начинал карьеру в подьячих Новгородской чети при В.И. Шуйском, затем был в Тушине, с января 1610 г. - у Сигизмунда III [5, c. 452]. В 1620/21 г. упоминается как изменник, живший в Новгороде Северском [3, с. 94].

Дьяк Сарыч Линев - д/д. с 1608 г. в Тушине [5, с. 200, 206], в апреле 1611 г. получил грамоту Сигизмунда «за верную службу» [26, с. 406], а в 1620/21 и 1622/1624 гг. - д. в Московском судном приказе [3, c. 294].

В Посольском приказе «сидел» думный дьяк и печатник Иван Тарасьевич Грамотин. С 1595 г. п. Посольского приказа [3, с. 129], был при Б. Годунове, Лжедмитрии I, В. Шуйском, в Тушине, «почал служить преж всех» в 1610 г. Сигизмунду III, одновременно «ведал» Поместный приказ в 1612 г., был послан в Польшу для ускорения приезда королевича Владислава и в составе русского посольства задерживался там до 1617 г. [5, с. 11, 17, 31, 211, 218-221]. Вернувшись, И.Т. Грамотин был назначен дьяком в Новгородскую четь, позднее ему было дано думное дьячество [3, с. 130]. В 1618 г. он передал целовальную запись М.Ф. Романову со шведским королем [7, стб. 321]. В 1618 г., после смерти Петра Третьякова, стал посольским дьяком [15, с. 109]. Был подвергнут опале в 1625 г.: отправлен на Алатырь, в 1634 г. возвращен и стал думным дьяком Посольского приказа, 2 июня 1634 г. - печатником [9, с. 144]. Умер 23 сентября 1638 г. [3, с. 130].

В прошлом подьячий, с 1598 г. [16, с. 199], дьяк В. Шуйского, д/д. Разрядного приказа Первого ополчения, Сыдавной Семен Зиновьевич Васильев во времена боярского правления «сидел» в Посольском приказе, в феврале 1612 г. - уже в ополчении Д. Трубецкого и И. Заруцкого, в период Соединенного ополчения совмещал работу в Разрядном и приказе Большого Дворца [5, с. 87, 144-146, 148, 216-218, 234]. При Михаиле Романове в 1615 г. его оклад составлял 7 руб. [25, стб. 17, 48, 73, 91, 272]. Его припись как думного дьяка имеется на Боярском приговоре в 1613 г. [27, с. 34] Во время церемонии венчания на царство Михаила Федоровича С.С.З. Васильев держал блюдо. Он «сказывал» дворянство К. Мини- 
ну, 13 июня «сказывал» государево жалование казначею В.Н. Траханиотову. В 1616 г. решил местнический спор Ф. Лыкова и Ф. Плещеева [7, стб. 99, $100,119]$. В 1616 г. получил оклад уже в размере 200 руб. [28, № 108, с. 139] В 1618 г. С.С.З. Васильев был указан в списке высших людей, «сидевших» в осаде в Москве [7, стб. 357]. В 1619 г. получил оклад в 200 рублей [9, с. 105].

Думный дьяк Петр Алексеевич Третьяков карьеру начал с подьячих в 1592 г. [16, с. 196], как дьяк прошел правительства Лжедмитрия I, Лжедмитрия II, был у московских бояр в августе 1610 г. и в ополчении Д.Т. Трубецкого и И.М. Заруцкого, подписал боярскую грамоту, а осенью 1612 г. вошел в новое правительство [5, с. 126, 127, 129, 150-153 и др.]. После воцарения М.Ф. Романова продолжил службу думным дьяком Посольского приказа до своей смерти в 1618 г. [3, с. 523]. Восстанавливая послужной список П.А. Третьякова, можно реконструировать всестороннюю работу Посольского приказа - это многочисленные документы деятельности приказа по посольским делам [7, стб. 224-225, 283, 310,] [29, c. 412-421; 30, с. 37]. От 1613-1617 гг. - о выплате жалованья служилым людям [45, № 5, стб. 150; 25, стб. 92], управлении Донской землей [31, № 8-10, стб. 35-41].

Думные дьяки приказа Василий Григорьевич Телепнев - посольский п. с 1604 г., при Лжедмитрии I, д., а затем д/д. при В. Шуйском [5, с. 493], и Томила Иудич Луговской - д. Разряда с 1604 г., д/д. при В. Шуйском [5, с. 472] были назначены в состав посольства в Польшу в августе 1610 г. [18, с. $258 ; 23$, № 290, с. 352], Т. Луговской был «в послах» задержан в Польше, вернулся из плена 1 июня 1619 г. [32, № 222 , с. $130-131 ; 24$, с. $78 ; 33$, № 8 , с. 31 , № 44, c. $186 ; 34$, с. $256 ; 35$, с. 122,257$]$ на должность д/д. Разрядного приказа, продолжил успешную карьеру при новом правительстве [3, с. 302]. О В.Г. Телепневе после выезда в Польшу ничего не известно.

В именной росписи московским послам (сентябрь 1610 г.) [26, № 182, с. $318 ; 36$, № 208, с. 451] значатся также подьячие, продолжившие службу при М. Романове: Юрий Данилов бежал от Сигизмунда в Москву и при М. Романове служил в Разрядном приказе [3, с. 144]; Григорий Ильин в 1615-1616 гг. был дозорщиком вотчины Чудова монастыря в Костроме [3, с. 217]; Федор Порошин - в 1618 г. п. в Переяславле Рязанском, упоминается в разных ведомствах до 1654 г. [3, с. 425]; Иван Трофимов - в справочнике С.Б. Веселовского при Михаиле Романове указано два Ивана Трофимовых [3, с. 524, 525], идентификация не представляется возможной ввиду широкого распространения имени; Федор Семенов при М. Романове - подьячий в Разряде в 1613/14 г., служил до 1638 г. [3, с. 472]. О подьячих из этого списка Иване Дашкове и Игнатии Дедкове сведений после 1613 г. нет.

В Поместном приказе, «почали служить Сигизмунду преж всех», сразу после распада Тушинского лагеря, думные дьяки Лжедмитрия II Иван Тарасьевич Грамотин - п. с 1595 г. [3, с. 129-130], д. с 1602 г. [5, с. 30] и Иван Иванович Чичерин - ранее известен только по Тушино [5, с. 201, 206], за что им были сохранены думные чины [36, № 208, с. 451] и даны поместья 30 марта 1610 г. Сигизмундом III по случаю избрания сына царем [26, с. 323,324$]$. В 1612 г. И.Т. Грамотин был послан в Польшу и удерживался в плену до 1617 г. [5, с. 216]. И.И. Чичерин после 1613 г. был только на воеводствах [3, с. 569; 2, c. 595].

Ряд грамот И.Т. Грамотин подписал с дьяками Герасимом Мартемьяновым - п. с 1595 г. [16, с. 189], д. с 1605 г. [5, с. 135], и Николаем Никитичем Новокщеновым - п. с 1596 г. [16, с. 189], д. с 1605 г. [5, c. 34, 36, 404] (сентябрь 1610 г., февраль, март 1611 г.) [23, № 310 , с. $367 ; 38$, с. $18,23-24,43$, 98; 39, c. 46]. С 1 июня 1611 г. Г. Мартемьянов и Н. Новокщенов перешли служить в ополчения.

Н.Н. Новокщенов при М.Ф. Романове продолжил служить в Поместном приказе до 1620 г. [21, с. 301, 320,411 ; 39, с. 47; 3, с. 376; 7, стб. 161, 203-204, 224225,$271 ; 28$, № 29-30, c. 129-130; 8, № 111, c. 223]. Летом 1617 г. был пожалован в Думу [7, стб. 299]. Карьера Н.Н. Новокщенова прервалась в связи с тем, что он неверно записал государев указ, за что был лишен думного чина, но продолжал иметь поместья, в 1630 г. известен как воевода в Перми, умер в 1637 г. [3, с. 376].

Г. Мартемьянов в 1615-1616 гг. - дворянин, участвовал в посольстве кн. И.М. Воротынского под Смоленск [25, стб. 753]. С апреля по август 1618 г. он состоял дьяком на Патриаршем дворе, в 16201621 гг. - д. в Сыскном приказе, в 1623-1625 гг. - в Тобольске, с декабря 1626 г. по 1634 г. - д. приказа Большого Дворца [3, с. 320]. В 1626-1627 гг. его оклад составлял 150 руб., как и в 1629 г. [9, с. 340].

Грамоты о земельных пожалованиях королевича Владислава содержат подписи подьячих приказа: Семен Клементьев Матчин, Гордей Бабанин (март 1611 г.), Домашка Васильев и Афонька Лукин сын Лебедев (1610/11 г., апрель 1611 г.), Василий Гаврилов (февраль 1611 г.), Томило Иванов (1610/11 г.), Афанасий Семенов Кадыев (июль 1611 г.), Постник Карпов (февраль - ноябрь 1611 г.), Иван Переяславцев (март 1611 г.), Бажен Степанов (март 1611 г.), Козейка Иванов сын Пироговский (сентябрь 1611 г.), Смирной Васильев $(1611 / 12$ г.) [38, с. 3, 9, 10, 15, 25, $33,34,39,40,62,63,71,81,88,89,103 ; 17$, c. $74 ; 40$, л. 6-7; 41, № 248, с. 522].

Известно, что продолжили приказную службу при Михаиле Романове из них: С.К. Матчин (п. там и же и по городам до 1639/40 г. [3, с. 325], В. Гаврилов (п. там же до 1615/16 г. [3, с. 114]), Б. Степанов (п. там же до 1638 г. [3, с. 490-491]).

У бояр в Разбойном приказе в 1611-1613 гг. служил дьяк Венедикт Кокушкин (Кокошкин) [2, с. 183], с 30 марта по 15 апреля 1614 г. был в Пскове [28, № 65 , c. 102 ; № 67 , с. 104 ; № 72 , c. $109-110$; № 85 , c. 127].

На Старом Земском дворе «при Литве» раньше всех стал служить дьяк Семейка Дмитриев, был пожалован поместьями от Сигизмунда III в марте и декабре 1610 г. [5, с. 190, 224-225]. До 1616/17 г. занимался также вопросами по разбойным делам [3, c. 154].

На Новом Земском дворе дьяк Афанасий Царевский - п. с 1604 г. [16, с. 199], «преж всех» начавший служить Сигизмунду III, пожалован поместьем 30 марта 1610 г., летом 1611 г. перешел в ополчение $[5$, с. $225,239,240]$ и 1 октября 1613 г. участвовал в 
походе против поляков вместе с Д.М. Черкасским [7, стб. 102]. В 1615-1616 гг. - дьяк Разбойного приказа [3, c. 558].

В Челобитном приказе «преж всех» стал служить Сигизмунду III казначей и думный дворянин Ф.И. Андронов (в чине дьяка, вероятно, не был), в Боярском списке 1610/11 г. напротив его фамилии есть помета: «...пущен при Литве из торговых мужиков и за измену повешен» [24, с. 77]. Дьяками приказа были Семен Федоров (п. с 1606 г.) и Третьяк Еремеев Горяинов (д. с 1606 г.) - их приписи есть на грамотах «царя Владислава» [5, с. 175, 192, 225]. Упоминания о службе после 1613 г. этих дьяков обнаружить не удается.

В Приказе Большого прихода известен подьячий Патрикей Насонов - п. с 1606 г. [5, с. 177, 221], в 1612 г. он значится в ополчении, а при М. Романове служил дьяком приказа Большого Дворца [42, с. 3, 13], и до 1625 г. - д. в приказе Холопьего суда, в 1626 г. - д. в Москве [3, с. 355].

О службе подьячего Ждана Безсонова после ноября 1610 г. [5, с. 221] не известно.

Дьяк Галицкой чети Андрей Романович Подлесов - д. с 1607 г. [5, с. 194, 222], при М. Романове был 4 августа 1613 г. на Двине, 12 декабря 1613 г. - в Варзуге, с 15 ноября 1614 г. по 6 июля 1615 г. - в Ямском приказе [25, с. 253, 269, 304], в 1615-1617 гг. - в Казани [2, с. 86], упоминается до 1631 г. в Ямском приказе и Астрахани [3, c. 416].

Новгородская четь. Степан Михайлов Соловецкий - д. в Тушине [5, с. 205, 206], приехал к Сигизмунду III под Смоленск вместе с Василием Михайловичем Юрьевым из Тушино 27 января 1610 г., С. Соловецкий получил чин думного дьяка, п. В.М. Юрьев - чин дьяка. Оба они были пожалованы поместьями [5, с. 150,205$]$, но после 1613 г. о них ничего не известно.

Дьяк Филипп Федорович Голенищев - д. с 1599 г. [16, с. 191], значится в списке «похлебцев Шуйского», которых следовало удалить из приказов при Сигизмунде III [23, № 310, с. 367]. Но Сигизмунд указал ему служить «где пригоже» [36, № 218, с. 483]. В росписи вещей от 20 февраля 1611 г. на продажу он упоминается вместе с д/д. С. Соловецким [43]. Дальнейшая судьба неизвестна.

По указу Сигизмунда III думным дьяком в Новгородскую четь был назначен Кирилл Сазонов Скоробовицкой (ранее упоминается 1 августа 1598 г. «из гостей» $[5$, с. 223]) и его было велено поверстать «против думных дьяков Разрядного и Посольского приказов» [3, с. 478]. Дальнейшая судьба неизвестна.

В Устюжской Чети «преж всех» с февраля 1610 г. начал служить Сигизмунду III дьяк Федор Никитич Апраксин - перешел из Тушинского лагеря, ранее не известен [5, с. 206, 224], в 1613 г. он подписался на выборах царя Михаила среди дьяков [19, № 203, с. 639], в 1614-1616 гг. сидел в Муроме [3, c. 28], с 21 декабря 1616 г. по 30 октября 1623 г. - д. приказа Казанского дворца [44, № 86, с. 120], затем до 1629 г. - в Новгороде, в 1629 г. его денежный оклад составлял 100 руб., поместный - 1000 четей [9, c. 42], до 1637 г. упоминается в Каменном, а затем в Ямском приказе [3, с. 28-29].

На службе в Приказе Казанского и Мещерского дворца до конца декабря 1610 г. оставались дьяки
Семен Ефимьев - п. с 1596/97 г. [16, с. 194], д. с 1604 г. [5, с. 25], и Алексей Захарьевич Шапилов - п. с 1590 г. [45, с. 204], д. с 1598 г. [5, с. 134]. Они дали присягу королевичу Владиславу и приводили к присяге казанский народ [5, с. 218]. Во время утверждения нового состава правительства в конце 1610 г. на место С. Ефимьева Сигизмунд III назначил в Большой дворец Богдана Губина, а на место дьяка А. Шапилова в Казанскую избу - Михаила Петровича Бегичева [36, № 218, с. 482; 26, с. 399].

Семейка Ефимьев все же остался на службе у Владислава и 9 марта 1611 г. его подпись имеется на памяти Г. Мартемьянову, память справил подьячий Пятой Ушаков [38, с. 24]. Больше о нем не известно. Дьяки А. Шапилов и М.П. Бегичев спустя некоторое время, в июле 1611 г., упоминаются в документах как приверженцы ополчений [5, с. 233, 234, 237]. При венчании на царство М.Ф. Романова А. Шапилов нес «стоянец» и держал блюдо [7, стб. 98-99]. В 1613-1614 гг. А.З. Шапилов стал думным дьяком [46, с. 20-22, 25-27, 31-35, 37-40], состоял на государевой службе до 1629 г. [3, с. 572]. М.П. Бегичев в 1613-1614 гг., возможно, служил в Конюшем приказе [47, л. 1]. В 1612-1613 гг. оклад его составлял 800 четей, в 1615-1616 гг. - голова (не дьяк) в объездах по Москве [3, с. 47], в 1615 г. - пятинщик на Ваге [9, c. 59].

Таможенный приказ как самостоятельное учреждение впервые упоминается в документах при Сигизмунде III. Лист на уряды на дьячество получил Бажен Замочников [5, с. 224], но до декабря 1610 г. и после 20 января 1611 г. о нем ничего не известно.

У дьяков - приверженцев Владислава и Сигизмунда III, чье точное место службы установить не удалось, карьера сложилась следующим образом.

Яков Мартинианов Демидов - п. с 1586 г. [3, с. 147], д. с 1600/01 г. [48, с. 114; 18, с. 194; 49, с. 332; 50, с. $120 ; 51$, л. 86 об.; 52, л. 95], перешел в Первое ополчение в Челобитный приказ, в феврале 1612 г. в Переславле Рязанском [5, с. 128, 129, 226], служил во Владимирском судном приказе в 1615 г. и в 1617 г. [7, стб. 186, 286].

Семен Владимирович Головин - п. с 1581 г. [3, c. 121], д. с 1608 г. [5, с. 187, 226], в 1611 г. изменил Владиславу и отъехал «в полки к ворам»; за что в июле 1611 г. его поместье в Суздале было отдано князю Г.П. Ромодановскому [38, с. 54], при М. Романове с 1614 по 1620 гг. «сидел» во главе Галицкой чети [25, с. 267-269], часто упоминается в дворцовых разрядах на государственных и посольских делах 1614-1617 гг. [7, стб. 132, 282-284, 304, 309].

Евстафий Александров Кувшинов - в Боярском списке 1610/11 г. с пометой «при Литве», ранее о нем не известно [5, с. 226-227], поддерживал идею признания королевича Владислава довольно долго: его подпись имеется на грамоте московского боярского правительства об этом в Кострому от 25 января 1612 г. [53, с. 85] Позже был лишен дьячества на некоторое время и был дозорщиком Устюга в 1619/20 г, затем упоминается в разных ведомствах дьяком до 1632/33 г. [3, с. 270].

Филимон Михайлович Озеров - д. с 1605 г. [5, c. 128], получил от Сигизмунда III лист на то, чтобы 
справить его по Московскому списку, летом 1613 г. собирал доходы в Галицком уезде [3, с. 384].

Дьяку Ивану Остафьеву в декабре 1610 г. возвращено старое поместье, отнятое В. Шуйским [5, с. 227], более не упоминается.

Антипов Иван Рубцов - д. с 1587 г. [16, с. 197], после марта 1611 г., когда он должен был по указу королевича Владислава выдать крымскому татарину Келибеку рубль на платье за крещение [5, с. 227], не упоминается.

Нет информации о дальнейшей судьбе подьячих площадного Богдана Ордабьева после 11 августа 1611 г., Ивашки Петрова Изъединова после 27 сентября 1610 г. и Абрама Ярыгина после 9 мая 1611 г. [5, c. 226-228].

В справочнике С.Б. Веселовского Филипп Семенов Ларионов ошибочно назван подьячим «царя Владислава» [5, с. 228].

Таким образом, дьяки и подьячие, служившие в приказах боярского правительства в годы лихолетья, несмотря на некогда данную присягу на верную службу польскому королевичу Владиславу и его отцу Сигизмунду III, вторгшемуся в Россию с целью ведения «московской войны», сумели удержаться при молодом правителе Михаиле Романове, а некоторые и при более суровом - царе и патриархе Филарете. Большая часть из них начали службу в конце XVI - начале XVII в. и в бурных событиях Смуты составляли штат служащих как законных представителей власти, так и самозванцев.

При распределении по категориям служащих видно, что из 9 думных дьяков Сигизмунда III только Петр Третьяков сразу после 1613 г. остался на службе и возглавил деятельность Посольского приказа во многом благодаря тому, что ранее недолго находился в составе боярского правительства и в 1612 г. перешел в правительство Второго (Нижегородского) ополчения К. Минина и Д. Пожарского.

2 думных дьяка снова оказались на службе после возвращения из польского плена в 1619 г. в составе посольства с Филаретом Романовым. Из 37 дьяков московских приказов продолжили свою профессиональную деятельность на службе Михаилу Романову после 1613 г. 22 человека, причем 12 из них - через службу в ополчениях. Из оставшихся 15 два дьяка умерли (или убиты), о судьбе 13 дьяков ничего не известно. То есть продолжили службу $60 \%$ дьяков Сигизмунда III. Некоторые дьяки стали думными и возглавили важнейшие ведомства, к примеру Н.Н. Новокщенов (Новокрещенов), С.С.З. Васильев.

Из 27 подьячих на службе при Михаиле Романове упоминаются 11 человек, точно известно, что 1 подьячий из них был в ополчениях. Судьба 16 остается неизвестной.

Почему по отношению к дьякам и подьячим М.Ф. Романов проявил такую лояльность и оставил на своих местах, даже дав возможность подняться по служебной лестнице? Такое положение дел могло быть вызвано главной причиной: М.Ф. Романову нужны были опытные управленцы. С возвращением Филарета из польского плена неугодные и скомпрометировавшие себя люди были устранены от власти - например, Ф.Ф. Лихачев, Е.Г. Телепнев. Некоторые - наоборот, из-за близкого знакомства с патриархом возвращены ко двору: И.Т. Грамотин, Т.И. Луговс- кой. Новое правительство Михаила Федоровича Романова не могло быть сформировано на пустом месте и, как и в предшествующие периоды Смуты, при смене правителей не могло обойтись без опыта чиновников прежнего центрального аппарата управления.

\section{СПИСОК ЛИТЕРАТУРЫ:}

1. Рыбалко Н.В., Дмитриева Е.Г., Малеева Е.С. Роль грамот патриарха Гермогена в организации земского ополчения 1611 года // Вестник Волгоградского государственного университета. Серия 4: История. Регионоведение. Международные отношения. 2017. № 1. C. 41-52.

2. Барсуков А. Списки городовых воевод и других лиц воеводского управления Московского государства XVII столетия по напечатанным правительственным актам. СПб.: Тип. М.М. Стасюлевича, $1902.611 \mathrm{c}$.

3. Веселовский С.Б. Дьяки и подьячие XV-XVII вв. М.: Наука, 1975. 607 с.

4. Лисейцев Д.В. Приказная система Московского государства в эпоху Смуты. М.; Тула: Гриф и К, 2009. $792 \mathrm{c}$.

5. Рыбалко Н.В. Российская приказная бюрократия в Смутное время начала XVII века. М.: Квадрига; МБА, 2011. $656 \mathrm{c}$.

6. Рыбалко Н.В. Власть и система центрального управления в Московском государстве в период Междуцарствия (1610-1613 гг.) // Власть, общество, индивид в средневековой Европе. М.: Наука, 2008. C. $96-124$.

7. Дворцовые разряды, по высочайшему повелению изданные II-м отделением его императорского величества канцелярии. Т. 1: 1612-1628 г. СПб.: в тип. ІІ Отделения Собственной Е.И.В. Канцелярии, 1850. 1184 стб.

8. Кормленая книга Костромской чети 16131627 гг. // Русская историческая библиотека, издаваемая Археографической комиссией (далее: РИБ). T. XV. СПб.: Тип. В.С. Балашева и К을 1894. С. $1-$ 209.

9. Демидова Н.Ф. Служилая бюрократия в России в начале XVII века (1625-1700). Биографический справочник. М.: Памятники исторической мысли, $2011.720 \mathrm{c}$.

10. Лихачев Н.П. Разрядные дьяки XVI века. Опыт исторического исследования. СПб.: Тип. В.С. Балашева, 1888.559 с.

11. Веселовский С.Б. Арзамасские поместные акты (1578-1618 гг.). М.: Императорское общество истории и древностей России при Московском университете, $1915.738 \mathrm{c}$.

12. Лисейцев Д.В. Судные приказы Московского царства в конце XVI - начале XVII века // Российская история. 2010. № 6. С. 106-115.

13. Российский государственный архив древних актов (РГАДА). Ф. 396. Московская Оружейная палата (1584-1831). Оп. 1. Ч. 23. № 36217. Расспросы и следственные приговоры о растрате государевой казны женою царя В.И. Шуйского.

14. Савва В.И. Дьяки и подьячие Посольского приказа в XVI веке: Справочник / сост. В.И. Савва; предисл. С.О. Шмидта. М.: Институт истории СССР AH CCCP, 1983. 228 c. 
15. Белокуров С.А. О Посольском приказе // Чтения ОИДР. М.: Изд-во ОИДР, 1906. Кн. 3.174 с.

16. Павлов А.П. Приказы и приказная бюрократия: (1584-1605 гг.) // Исторические записки. М.: Наука, 1988. Т. 116. С. 187-227.

17. Духовные и сговорные грамоты // Сборник актов, собранных в архивах и библиотеках. Вып. $1 /$ Н.П. Лихачев. СПб.: тип. В. Балашева и $\mathrm{K}^{\circ}, 1895$. C. 3-119.

18. Разрядная книга 1550-1636 гг. Вып. 2 / сост. Л.Ф. Кузьмина; отв. ред. В.И. Буганов. М.: Изд. АН CCCP, 1976. $242 \mathrm{c}$.

19. Собрание государственных грамот и договоров, хранящихся в государственной коллегии иностранных дел (далее: СГГиД): в 5 ч. Ч. 1. М.: Тип. Н.С. Всеволожского, 1813. 533 с.

20. РИБ: в 39 т. Т. 2 [Акты]. СПб.: в тип. братьев Пантелеевых, 1875. 656 с.

21. Сторожев В.Н. Материалы для истории Поместного приказа по Вологодскому уезду в XVII веке. Вып. 1. СПб.: Тип. Имп. АН., 1906. 463 с.

22. Белокуров С.А. Разрядные записи за Смутное время (7113-7121 гг.) // Чтения ОИДР. М.: Изд. ОИДР, 1907. Кн. 2, 3. 312 c.

23. Акты исторические, собранные и изданные Археографическою комиссиею: в 5 т. Т. 2. (15981613 гг.). СПб.: Тип. Экспедиции заготовления гос. бумаг, $1841.438 \mathrm{c}$.

24. Боярский список 1610-1611 гг. // Чтения ОИДР. М., 1909. Кн. 3. С. 73-163.

25. Приходно-расходные книги Московских приказов // РИБ. Т. XXVIII. СПб.: Синод. тип., 1912. $513 \mathrm{c}$.

26. Акты, относящиеся к истории Западной России. Т. 4. 1588-1632. СПб., Тип. Эдуарда Праца, $1851.582 \mathrm{c}$.

27. Указная книга Поместного приказа / В.Н. Сторожев. М.: Тип. товарищества И.Н. Кушнерев и $\mathrm{K}^{\circ}$, 1889. $231 \mathrm{c}$.

28. Акты Московского государства / под ред. Н.А. Попова, Д.Я. Самоквасова: в 3 т. Т. 1 (15711634 гг.). СПб.: Тип. Имп. Акад. наук, 1890. 767 с.

29. Веселовский Н.П. Памятники дипломатических сношений Московской Руси с Персией. СПб.: Лештуковская паровая скоропечатная П.О. Яблонского, $1892.465 \mathrm{c}$.

30. Посольская книга по связям России с Англией 1614-1617 гг. / сост. текста, вступительной статьи, комментариев и указателей Д.В. Лисейцев. М.: ИРИ PAH, 2006. $396 \mathrm{c}$.

31. Донские дела. Книга I // РИБ. Т. XVIII. СПб.: Тип. ГУУ, 1898. 1006 стб.

32. Памятники обороны Смоленска (1609-1611 гг.) // Чтения ОИДР. М.: Изд. ОИДР, 1912. Кн. 1. С. 1261 (Смутное время московского государства, 16041613 гг. Вып. 6).

33. СГГиД: в 5 ч. Ч. 3. М.: Тип. Селивановского, $1822.556 \mathrm{c}$.

34. Бельский летописец // Полное собрание русских летописей. Т. 34. М.: Наука, 1978. С. 238-271.

35. Новый летописец // Временник ОИДР. Кн. 17. М.: Изд. ОИДР, 1853. С. 1-212.

36. СГГиД: в 5 ч. Ч. 2. М.: Тип. Селивановского, 1819.638 с
37. Барсуков А. Списки городовых воевод и других лиц воеводского управления Московского государства XVII столетия по напечатанным правительственным актам. СПб.: Тип. М.М. Стасюлевича. $1902.611 \mathrm{c}$.

38. Сухотин Л.М. Земельные пожалования в Московском государстве при царе Владиславе, 16101611 гг. // Чтения ОИДР. М.: Изд. ОИДР, 1911. Кн. 4. C. $1-180$.

39. Шумаков С.А. Экскурсы по истории Поместного приказа. М.: Синод. тип., 1910.79 с.

40. РГАДА. Ф. 141. Приказные дела старых лет. Оп. 1. (1505-1706 гг.). Д. 2. Устюжская четверть.

41. Акты писцового дела: Материалы для истории кадастра и прямого обложения в Московском государстве: В 2 т. / Собрал и ред. С.Б. Веселовский. Т. 1 (1587-1627 гг.) // Чтения ОИДР. М., 1913. Кн. 2-4. $666 \mathrm{c}$.

42. Сухотин Л.М. Первые месяцы царствования Михаила Федоровича (Столпцы Печатного приказа) Л.М. Сухотин. М.: Императорское общество истории и древностей России при Московском университете, 1915. 238 c.

43. РГАДА. Ф. 396. Московская Оружейная палата (1584-1831 гг.).Оп. 1.Ч. 23. № 36212. Февраль 1611 г. Роспись, что взято у дьяков у думного у Степана Соловецкого да у Филиппа Голенищева в продажу к дьяку Марку Поздееву да к гостям.

44. Акты, собранные в библиотеках и архивах Российской империи археографическою экспедициею императорской академии наук: в 4 т. СПб.: в тип. 2 отд. Собственной Е.И.В. канцелярии, 1836. Т. 3. $518 \mathrm{c}$.

45. Сборник Муханова / А.П. Муханов. СПб.: Тип. Эд. Праца, 1866.799 с.

46. Приходно-расходная книга Казенного приказа 1613-1614 гг. // РИБ. Т.ІХ. СПб.: Тип. МВД, 1884. C. $1-384$.

47. РГАДА. Ф. 396. Московская Оружейная палата (1584-1831). Оп. 1. Ед. хр. 28. Память дьяку Михаилу Бегичеву о покупке на Государеву конюшню племенного жеребца.

48. Разрядная книга 1475-1605 гг. Т. 4. Ч. 1. / сост. Л.Ф. Кузьмина; под ред. В.И. Буганова. М.: Изд-во ИИ РАН,1994. 140 с.

49. Разрядная книга 1559-1605 гг. Ч. 2. / сост. Л.Ф. Кузьмина. М.: Наука, 1974. 436 с.

50. Разрядные книги 1598-1638 гг. М.: Наука, 1974. 398 c.

51. РГАДА. Ф. 199. Портфели Миллера (12651783 гг.). Оп. 1. Ч. 1. Порт. 159. Ч. 2. Разряды $1598-$ 1636 гг.

52. РГАДА. Ф. 199. Портфели Миллера (12651783 гг.). Оп. 1. Ч. 1. Порт. 130. Ч. 2. № 1. Книга, содержит известия, выписанные из Разрядного архива с 1598 г. по 1604 г.

53. Памятники истории Смутного времени / под ред. А.И. Яковлева. М.: Издание Н.Н. Клочкова, 1909. $104 \mathrm{c}$.

Исследование выполнено при финансовой поддержке РФФИ, проект «Институты государственного управления в России в Смутное время начала XVII века» № 15-31-01202 (a2). 
THE ORDERLY PROTÉGÉS OF SIGISMUND III UNDER THE NEW TSAR M.F. ROMANOV

(C) 2017

Rybalko Natalia Vladimirovna, candidate of historical sciences, associate professor of History Department

Ivina Anastasia Viktorovna, curator of collections of Museum Complex

Volgograd State University (Volgograd, Russian Federation)

Abstract. This paper discusses the key issue of the system management of the transition period - from the time of the Interregnum of Moscow State to the formation of the government of the new sovereign, Mikhail Romanov. Biographies of deacons and scribes of the closing period of Troubles are restored according to individual mentions, mainly in the act material and documents of official records management. Using the method of prosopography, the authors have systematized biographical information of individuals and analyzed collective portrait of employees, which allowed to reveal the general state policy in relation to the managers of higher and middle level of the central administrative apparatus. As a result of the study, it was possible to establish that 36 from 73 persons, fixed in the service in the boyar government of Moscow and under Sigismund III continued to work in the new government of Mikhail Romanov. From the 9 Duma clerks - 3 people, from 37 clerks - 22 people, from 27 junior employees at Mikhail Romanov - 11 people. The removal touched, mainly, the Duma clerks. Most of middle-level employees like professional managers were not suspended from work for political reasons, which correlates with the general trend of the Trouble Time at the beginning of the 17 century. $60 \%$ of middle-level employees of Boyar government, which previously supported the power of Sigismund III, continued their work in the new government of Mikhail Romanov.

Keywords: Time of Troubles; Russian history; Moscow State; 17 century; Interregnum; clerks; Duma secretaries; scribes; orders; Mikhail Romanov; Sigismund III; method of prosopography; reconstruction of biographies; central administration; boyar government; clerical employees; government of Tsar Mikhail Romanov.

УДК 94 (47). 06

Статья поступила в редакцию 27.09.2017

\section{РУССКИЙ ТЕАТР В БЕРЛИНЕ (1919-1923 ГГ.): ОПЫТ КУЛЬТУРНОГО ЭКСПОРТА}

(C) 2017

Попов Максим Евгеньевич, магистрант кафедры истории России

Горно-Алтайский государственный университет (г. Горно-Алтайск, Российская Федерация)

Аннотация. Статья посвящена рассмотрению русской театральной деятельности в Берлине в период 1919-1923-х гг., когда Берлин являлся сосредоточием русской театральной жизни за рубежом, в этой связи происходил активный творческий взаимообмен между немецкой и русской культурами. Проблема экспорта российской художественной культуры в страны Запада представляет интерес как для отечественных, так и зарубежных исследователей. Среди актуальных вопросов по данной проблеме важное место занимает деятельность русского театра. Изучение данного вопроса позволяет получить представление о потенциале российской культуры в иной социальной и культурной среде. В центре исследования находится процесс становления и развития русской театральной жизни в немецкой культурной среде. Автором предпринята попытка выделения и раскрытия основных художественных направлений русского театра в Берлине в 1919-1923-х гг. и определения их роли в приобщении Германии к достижениям отечественной культуры. В работе использованы материалы из воспоминаний современников и периодической печати. На основании данных источников показано, что театр осуществлял одну из основополагающих ролей в сохранении русского культурной общности и их культурного облика за границей. Русские театральные сезоны способствовали приобщению Запада к достижениям отечественной культуры и налаживанию культурных и художественных связей между Германией и Советской Россией. Таким образом, деятельность эмигрантского и гастрольного русского театра в Берлине в 1919-1923-х гг. отразила высокий потенциал русской культуры в условиях чужой социальной среды.

Ключевые слова: русский эмигрантский театр; гастролирующий театр; Берлин; Германия; спектакль; постановка; камерный театр; «Синяя птица»; «Ванька-Встанька»; «Кикимора»; Московский Художественный театр Станиславского; Московский Художественный передвижной театр; российская художественная культура.

Активность русской театральной деятельности в Берлине 1919-1923-х гг. была обусловлена относительной близостью Германии к границам Советской России, взаимными экономическими интересами и прочностью культурных отношений. Для большевиков Берлин представлялся открытыми воротами в Европу, к тому же после подписания Рапалльского договора в Берлине увеличилось влияние русской культуры.

Существенную роль в экспорте российской художественной культуры в Германию сыграла эмиграция первой волны. Ее насыщенная культурная жизнь в Берлине проходила на фоне гиперинфляции
1919-1923 гг. В результате стремительного падения стоимости немецкой марки [1, с. 116] доллар - главная валюта иностранцев в Германии - приобретал все большую ценность, что способствовало увеличению числа русско-эмигрантского потока.

Из-за большого наплыва русских эмигрантов происходило своего рода «обрусение Берлина». Неизбежным следствием данного процесса явилось распространение русской культуры в немецкой среде. Возникновение моды на так называемый «русский стиль» стало благодатной почвой для развития русского театра за рубежом, поскольку русский театр, как и любой театр, представлял собой искусство 